\title{
Nama-Nama Pesantren di Bandung Raya (Kajian Sosiolinguistik)
}

\begin{abstract}
Abdul Kosim ${ }^{1}$
DOI: https://doi.org/10.52593/klm.02.1.01

Naskah diterima: 29-12-2020, direvisi: 22-01-2021, disetujui: 25-01-2021

Abstraksi

Penelitian ini menjelaskan fenomena interferensi Bahasa Arab pada nama-nama pesantren yang tersebar di Bandung Raya. Metode yang digunakan dalam penelitian ini adalah metode deskriptif-kualitatif. Data-data ini diperoleh dengan cara mengambil dari daerah-daerah refresentatif untuk mewakili daerah sekitar kota Bandung. Data-data tersebut dikumpulkan, diklasifikasi, dianalisis, kemudian disimpulkan berdasarkan kajian kebahasaan yaitu interferensi Bahasa Arab aspek morfologi dan sintaksis dalam ruang lingkup sosiolinguistik. Bahasa Arab bagi penduduk Indonesia sudah sangat melekat dalam kehidupan sehari-hari, bahkan sudah melekat dengan sosial budaya kehidupan masyarakat Indonesia. Hal ini terlihat dalam nama-nama orang di Indonesia sangat banyak yang diambil dari Bahasa Arab. Selain itu nama-nama lembaga baik formal maupun non formal banyak yang menggunakan Bahasa Arab. Nama-nama pesantren di Indonesia contohnya hampir sebagian besar menggunakan Bahasa Arab, baik secara langsung ataupun dengan dilatinkan dan transliterasi. Ditemukan bahwasannya interferensi Bahasa Arab pada nama-nama pesantren yang tersebar di Bandung Raya terdapat 7 data (25\%) menggunakan struktur badal, 17 data (61\%) menggunakan struktur idhofat, 1 data (3\%) menggunakan struktur sifat, dan 3 data (11\%) strukturnya tidak berterima secara kaidah Bahasa Arab.
\end{abstract}

Kata kunci: Pesantren, Interferensi, Sosiolinguistik

\section{A. Pendahuluan}

Bahasa Arab merupakan bahasa internasional kedua setelah Bahasa Inggris. Bahasa Arab merupakan bahasa yang digunakan oleh bangsa-bangsa Arab ketika berkomunikasi dalam kehidupannya sehari-hari. Bahasa Arab adalah bahasa yang berafiliasi ke dalam Bahasa Syam (Smit), bahasa Al-Qur'an, dan bahasa kitab-kitab samawi yang dipercayai oleh orang-orang beriman dan yang dagunakan oleh 22 Negara Arab serta diketahui oleh jutaan Umat Islam sebagai bahasa agama Islam. ${ }^{2}$

Uraian di atas menjelaskan bahwasannya Bahasa Arab memiliki hubungan yang erat dengan Islam. Al-Khuli (1982:19) menambahkan bahwasannya urgensi Bahasa Arab bagi umat Islam adalah sebagai berikut:

1. Bahasa Arab sebagai bahasa Al-Qur'an;

2. Bahasa Arab sebagai bahasa Al-Hadis;

3. Bahasa Arab sebagai bahasa yang digunakan dalam ibadah shalat;

\footnotetext{
${ }^{1}$ Pendidikan Bahasa Arab STAI Dr. KHEZ. Muttaqien, abdoelmahir87@ yahoo.com

${ }^{2}$ Muhammad Ali Al-Khuli, A Dictionary of Throretical Linguistics (Beirut: Librarie Du Liban, 1991), 21
} 
4. Bahasa Arab sebagai bahasa perekonomian dunia. ${ }^{3}$

Bahasa Arab dengan urgensinya seperti dijelaskan di atas akan tetap eksis dalam kehidupan manusia terutama bagi umat Islam, bahkan sampai akhir zaman nanti. Umat Islam memiliki kebutuhan tersendiri terhadap Bahasa Arab salah satunya sebagai alat untuk memahami referensi-referensi ajaran agama dan sumber ilmu pengetahuan yang sebagain besar menggunakan Bahasa Arab.

Bahasa Arab di Indonesia memiliki peranan yang sangat strategis karena Negra Indonesia merupakan Negara dengan penduduk umat Islam terbesar di dunia. Bahasa Arab di Indonesia dipelajari di lembaga-lembaga pendidikan baik formal maupun non formal. Lembaga formal contohnya di lembaga-lembaga pendidikan dari mulai pendidikan dasar/ madrasah ibtidaiyah sampai perguruan tinggi. Adapun lembaga non formal seperti pesantren-pesantren di Indonesia sebagain besar mempelajari Bahasa Arab baik sebagai ilmu ataupun sebagai alat komunikasi.

Bahasa Arab bagi penduduk Indonesia sudah sangat melekat dalam kehidupan sehari-hari, bahkan sudah melekat dengan sosial budaya kehidupan masyarakat Indonesia. Hal ini terlihat dalam nama-nama orang di Indonesia sangat banyak yang diambil dari Bahasa Arab. Selain itu nama-nama lembaga baik formal maupun non formal banyak yang menggunakan Bahasa Arab. Nama-nama pesantren di Indonesia contohnya hampir sebagian besar menggunakan Bahasa Arab, baik secara langsung ataupun dengan dilatinkan dan transliterasi. Uniknya sebagaian besar nama-nama pesantren tersebut yang tertulis lengkap dengan Bahasa Arab setelah diamati oleh penulis gaya penulisannya berbeda-beda, diantaranya ada yang menggunakan kaidah Bahasa Arab, ada yang menggunakan Bahasa Arab dengan kaidah Bahasa Indonesia, bahkan ada yang secara kaidah Bahasa Arab itu salah atau keliru. Kesalahan dalam berbahasa menurut para linguis bisa dikategorikan ke dalam interferensi bahasa. Melihat fenomena tersebut, penulis merasa berkepentingan untuk memecahkan masalah tersebut dengan sebuah penelitian ilmiah yang menggunakan pendekatan linguistik Bahasa Arab. Pendekatan linguistic ini dimaksudkan untuk menggali makna yang terkandung dalam struktur-struktur yang digunakan dalam penulisan nama-nama pesantren yang menggunakan Bahasa Arab, karena dalam Bahasa Arab setiap struktur memiliki pesan makna tersendiri di dalamnya.

\footnotetext{
${ }^{3}$ Muhammad Ali Al-Khuli, Asalibu Tadris Al-Lughah Al-Arabiyah (Riyadh, 1982), 19.
} 


\section{B. Teori / Konsep}

\section{Variasi Bahasa}

Variasi bahasa merupakan fenomena yang terjadi pada komunitas berbahasa pada masyarakat. Bahasa yang bersifat dinamis mendorong adanya beberapa fenomena yang terjadi di masyarakat, diantaranya adalah perubahan dan variasi bahasa. Variasi bahasa adalah macam-macam bentuk yang ada dalam suatu bahasa ${ }^{4}$ Aneka ragam bentuk yang terjadi dalam suatu bahasa bisa dari aspek bunyi, kosakata, struktur, dan makna. Variasi bahasa disebabkan oleh kegiatan interkasi sosial yang dilakukan oleh masyarakat atau kelompok yang sangat beragam dan dikarenakan penuturnya yang tidak homogen.

Dalam hal variasi bahasa ini ada dua pandangan. Pertama, variasi itu dilihat sebagai akibat adanya keragaman sosial penutur bahasa itu dan keragaman fungsi bahasa. Kedua, variasi bahasa itu ada untuk memenuhi fungsinya sebagai alat interaksi dalam kegiatan masyarakat yang beraneka ragam. Kedua pandangan ini dapat saja diterima ataupun ditolak. Yang jelas, variasi bahasa itu dapat diklasifikasikan berdasarkan adanya sosial dan fungsi kegiatan di dalam masyarakat

Adapun Pateda membagi variasi bahasa berdasarkan : tempat, waktu, pemakai, pemakaiannya, situasi, dan status. Dari segi waktu menghasilkan variasi bahasa yang disebut dialek temporal, dari segi penggunannya menghasilkan apa yang disebut diglosia, kreol, bahasa lisan, nonstandard, pijin, register, reportories, seputation, standar, bahasa tulis, bahasa tutur sapa, kan dan jargon. Dari segi situasi dapat dibagi atas bahasa ibu, bahasa daerah, lingual franca, bahasa nasional, bahasa Negara, bahasa pengantar, bahasa persatuan dan bahasa resmi dan akan terlihat pada kita bahwa komunikasi pada situasi tidak formal.

\section{Interferensi}

Interferensi merupakan fenomena yang terjadi pada masyarakat bilingual ataupun multilingual yaitu masyarakat yang mempelajari dan menguasai dua bahasa atau lebih. Interferensi adalah proses perpindahan suatu bahasa dan kaidahnya dari bahasa ibu ke bahasa kedua. ${ }^{5}$ Interferensi terjadi apabila ada suatu penyimpangan dalam penggunaan bahasa dari norma-norma yang ada sebagai akibat adanya kontak bahasa atau pengenalan lebih dari satu bahasa. ${ }^{6}$ Interferensi merupakan kekeliruan yang disebabkan terbawanya kebiasaan dialek

\footnotetext{
${ }^{4}$ Muhammad Afifudin Dimyati, Madkhal Ila Ilmi Al-Lughah Al-Ijtima 'i (Surabaya: Lisan Arabi, 2016), 50 .

${ }^{5}$ Muhammad Afifudin Dimyati, Madkhal Ila Ilmi Al-Lughah Al-Ijtima'i (Surabaya: Lisan Arabi. 2016), 82.

${ }^{6}$ Ubaidillah. 2012. "Interferensi Penggunaan Nama Diri Berbahasa Arab Di Indonesia (Sebuah Kajian Sosiolinguistik),.” Adabiyyāt: Jurnal Bahasa dan Sastra 10(1),: 1.
} 
dalam bahasa pertama ke dialek bahasa ke dua. ${ }^{7}$ Dari beberapa pengertian tersebut dapat disimpulkan bahwasannya interferensi merupakan sebuah konsekuensi yang terjadi pada kalangan masyarakat ketika mempelajari dan menggunakan bahasa lebih dari satu bahasa.

Konsekuensi tersebut bisa tergolong ke dalam kekeliruan bahkan kesalahan.

Interferensi Bahasa Arab pada masyarakat Indonesia terjadi pada beberapa aspek, diantaranya pada aspek fonologi, aspek morfologi, aspek kosakata, aspek sintaksis, dan aspek semantik. Dalam penelitian ini yang menjadi focus penelitian adalah fenomena interferensi pada aspek morfologi dan sintaksis. Interferensi pada aspek morfologi contohnya para pelajar Indonesia yang belajar Bahasa Arab mereka mengatakan اثنتين كر اسة catau

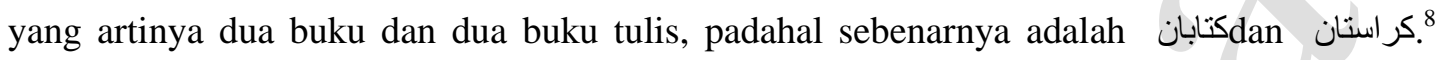
Adapun interferensi pada aspek sintaksis adalah sistem bahasa pertama masuk ke dalam sistem bahasa kedua, contohnya الطالبات مجذّ لمدرستان بعيدةyang artinya dua sekolah itu berjauhan dan para siswi itu bersungguh-sunggu. Ungkapan dalam struktur tersebut tidak sesuai dengan kaidah bahasa kedua yaitu Bahasa Arab.

3. Sintaksis

Suatu bentuk apabila dirangkai dengan bentuk yang lainnya untuk melahirkan sebuah makna maka rangkaian tersebut dalam ilmu bahasa adalah sintaksis. Sintaksis merupakan cabang linguistik yang mengkaji hubungan antarkata dalam suatu kontruksi. ${ }^{9}$ Sintaksis mendeskripsikan bagaimana sebuah kalimat dibangun dari kosakata. Selain itu sintaksis mendeskripsikan kelas kata yang memiliki potensi untuk menempati posisi dalam sebuah kalimat. ${ }^{10}$ Sintaksis dalam Bahasa Arab disebut dengan ilmu nahwu. Ilmu nahwu adalah ilmu yang mempelajari kedudukan sebuah kata ketika sudah berada dalam sebuah kalimat. ${ }^{11}$ Dengan demikian sintaksis merupakan ilmu yang mengkaji rangkaian kata-kata yang didistribusikan dalam sebuah kalimat dan memiliki makna yang sempurna.

Sintaksis dalam Bahasa Arab memiliki karakteristik tersendiri yang berbeda dengan sintaksis dalam bahasa yang lainnya. Diantaranya dalam Bahasa Arab sintaksis dirinci kembali menjadi ilmu tarkib atau ilmu tentang strukur. Struktur dalam Bahasa Arab diantaranya ada yang disebut dengan tarkib washfi, tarkib idhafi dan tarkib badal . Tarkib washfi adalah susunan yang terdiri dari nomina dan adjektif contohnya محد ماهر 'Muhammad yang pandai' sedangkan tarkib idhofi adalah susunan yang terdiri dari

${ }^{7}$ Rahmawati, Ana. 2018. "Bentuk Interferensi Sintaksis Bahasa Indonesia Dalam Berbahasa Arab." Ijaz Arabi Journal of Arabic Learning 1(2),: 122-29.

${ }^{8}$ Muhammad Afifudin Dimyati, Madkhal Ila Ilmi Al-Lughah Al-Ijtima'i (Surabaya: Lisan Arabi.2016), 87.

${ }^{9}$ Ade Nandang dkk, Pengantar Linguistik Arab (Bandung: PT Remaja Rosdakarya. 2018), 82.

${ }^{10}$ Ramdiani, Yeni et al. "Sintaksis Bahasa Arab (Sebuah Kajian Deskriptif)"

${ }^{11}$ Tajudin Nur, Morfologi Bahasa Arab (Sumedang: Unpad Press. 2018), 18. 
gabungan nomina dengan nomina contohnya رئيس المدرسة'kepala sekolah’. Tarkib badal adalah susunan yang terdiri dari badal (pengganti) dan mubdal minhu (yang diganti) contohnya seperti حضر الخليفة عمر بن الخطاب"telah datang khalifah, Umar bin Khathab.

Berbedanya struktur kata tentunya mengakibatkan perbedaan konotasi makna, begitupun masing-masing struktur kata yang telah disebutkan memiliki makna khususnya masing-masing. As-Samira'i menyebutkan bahwa tarkib idhafi memiliki sekurangkurangnya 3 makna ; 1) menyimpan makna Jseperti غلام هند"(budak milik Hindun”, 2)

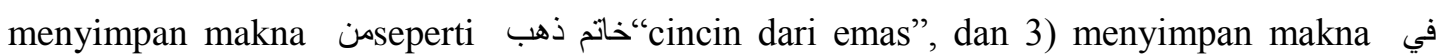
seperti ثهيد الدار“yang syahid di dalam rumah”. Tarkib wawshfi sekurang-kurangnya memiliki makna berikut ; 1) attakhshish, seperti contoh مررت برجل طويل, 2) at-taudhih,

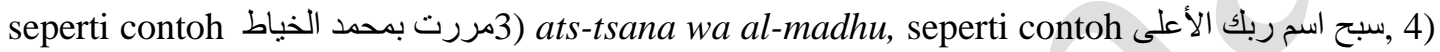
adz-dzam wa at-tahqir, seperti contoh at-tarhim, seperti contoh

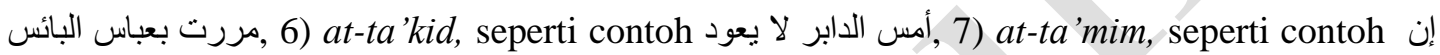

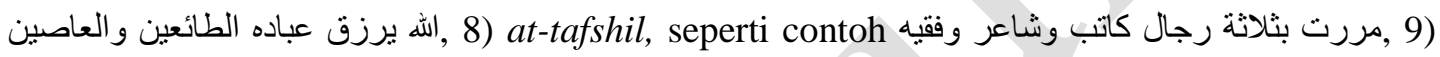
al-ibham, seperti contoh كتبت له رسالة حسنة أو سيئة (8dapun tarkib badal terutama bada وعلى mathabiq, memiliki makna khas al-idhah wa at-tabyin ba'da al-ibham seperti contoh

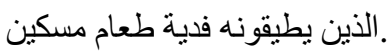

\section{Metode Penelitian}

Metode yang digunakan dalam penelitian ini adalah metode deskriptif-kualitatif. Deskripsi bermanfaat untuk mengambarkan ciri-ciri data secara akurat sesuai dengan sifat alamiah itu sendiri. ${ }^{12}$ Penelitian ini menjelaskan fenomena interferensi Bahasa Arab pada namanama pesantren yang tersebar di kota Bandung. Data-data ini diperoleh dengan cara mengambil dari daerah-daerah refresentatif untuk mewakili daerah sekitar kota Bandung. Data-data tersebut dikumpulkan, diklasifikasi, dianalisis, kemudian disimpulkan berdasarkan kajian kebahasaan yaitu interferensi Bahasa Arab aspek morfologi dan sintaksis dalam ruang lingkup sosiolinguistik.

Penelitian ini terdiri atas tiga tahap penelitian, meliputi pengumpulan data, analisis data dan penyajian hasil analisis data.

1. Metode dan Teknik Pengumpulan Data

Pengumpulan data dalam penelitian ini menggunakan metode simak. Metode ini dilakukan dengan menyimak penggunaan bahasa, metode ini disebut juga dengan metode pengamatan atau observasi. ${ }^{13}$ Kemudian teknik yang dilakukan dalam penelitian ini adalah

${ }^{12}$ Fatimah Djadjasudarma, Metode Linguistik (Bandung: Refika Aditama. 2010), 11.

${ }^{13}$ Sudaryanto, Metode dan Aneka Teknik Analisis Bahasa (Yogyakarta: USD Press. 2015), 203. 
teknik catat. Teknik catat dilakukan dengan cara pencatatan pada kartu data yang segera dilanjutkan dengan klasifikasi. Data dalam penelitian ini adalah data tulis yang diperoleh dari penulisan nama-nama pesantren di kota Bandung.

2. Metode dan Teknik Analisis Data

Analisis data merupakan salah satu langkah dalam penelitian untuk menjelaskan suatu data yang terhimpun dianalisis dengan langkah-langkah tertentu. Adapun analisis yang akan dilakukan dalam penelitian ini menggunakan metode padan intralingual. Metode padan intralingual mengacu pada makna unsur-unsur yang berada dalam bahasa seperti hal-hal yang menyangkut makna, informasi, konteks tuturan, dan lain-lain. ${ }^{14}$ Dalam penelitian ini unsur bahasa yang diteliti adalah interferensi pada aspek morfologi dan sintaksis pada namanama pesantren yang ditulis menggunakan Bahasa Arab.

3. Metode dan Teknik Penyajian Hasil Analisis Data

Hasil analisis data yang berupa temuan penelitian sebagai jawaban atas masalah yang hendak dipecahkan haruslah dijadikan dalam bentuk teori. Dalam menyajikan hasil penelitian ini menggunakan metode informal. ${ }^{15}$ Metode informal digunakan pada pemaparan hasil analisis data yang berupa kata-kata atau uraian biasa tanpa lambang-lambang formal yang sifatnya teknis. Penyajian hasil penelitian berupa penjelasan-penjelasan sistematis tentang fenomena interferensi morfologi dan sintaksis pada penulisan nama-nama pesantren yang menggunakan Bahasa Arab di kota Bandung.

\section{Hasil dan Pembahasan}

1. Data Nama-Nama Pesantren di Wilayah Bandung

Setelah penulis amati, penulis menemukan 28 sampel nama-nama pesantren yang berada di wilayah Bandung yang secara geografis dapat diklasifikasi menjadi: 1) Kabupaten Bandung : 19 data; 2) Kota Bandung : 6 data; 3) Kabupaten Bandung Barat : 2 data; 4) Kota Cimahi : 1 data.

Data nama-nama pesantren yang menjadi sampel dapat dilihat pada tabel berikut:

\begin{tabular}{|c|r|r|r|}
\hline No & Nama & Lokasi & Kawasan \\
\hline 1 & مؤسسة التربية الإسلامبة مفتاح & Cileunyi & Kab. Bandung \\
& & & \\
\hline
\end{tabular}

${ }^{14}$ Mahsun, Metode Penelitian Bahasa (Jakarta: Rajawali Pers. 2014), 118.
${ }^{15}$ Ibid., 279.

6 | Kalamuna: P-ISSN: 2655-4267, E-ISSN: 2745-6943 
Nama-Nama Pesantren... (Abdul Kosim)

\begin{tabular}{|c|c|c|c|}
\hline 2 & معهد اللغة العربية & Cileunyi & Kab. Bandung \\
\hline 3 & معهد الر ائد الإ & Cibiru & Kota Bandung \\
\hline 4 & المعهد اللغوي & Cibiru & Kota Bandung \\
\hline 5 & معهد المرضية الإسلامية & Cileunyi & Kab. Bandung \\
\hline 6 & المعهد الإسلامية السلفية نهج السلام & Cileunyi & Kab. Bandung \\
\hline 7 & المعهد الإ & Cileunyi & Kab. Bandung \\
\hline 8 & المعهد الإسلاد & Cileunyi & Kab. Bandung \\
\hline 9 & معه & Cicalengka & Kab. Bandung \\
\hline 10 & المعهد دار الفط & Ciparay & Kab. Bandung \\
\hline 11 & مؤسسة د & Cibiru & Kota Bandung \\
\hline 12 & هـ & Cibiru & Kota Bandung \\
\hline 13 & معهد شمس العلوم محمدية & Ujungberung & Kota Bandung \\
\hline 14 & المعهد الإسلاه & Cikancung & Kab. Bandung \\
\hline 15 & معهد التربية الإسلامبة فتح المعين & Cileunyi & Kab. Bandung \\
\hline 16 & معهد مفتاح السعادة الإسـلامي & Banjaran & Kab. Bandung \\
\hline 17 & معهد دار الحكم الإسلامي & Pangalengan & Kab. Bandung \\
\hline
\end{tabular}


Kalamuna, Vol. 2. No. 1, Januari 2021. $01-23$

\begin{tabular}{|c|c|c|c|}
\hline 18 & معهد التسليم الثانية & Pangalengan & Kab. Bandung \\
\hline 19 & المعهد المختارية الإسلامية & Mande & Kab. Bandung Barat \\
\hline 20 & مي الفطرى & Pangalengan & Kab. Bandung \\
\hline 21 & ل إِسلامي & Pacet & Kab. Bandung \\
\hline 22 & & Pacet & Kab. Bandung \\
\hline 23 & & Cimahi & Kota Cimahi \\
\hline 24 & ج الإسلامي & Cililin & Kab. Bandung Barat \\
\hline 25 & معهد البشرية للتربية الإسلامية & Cigondewah & Kota Bandung \\
\hline 26 & سلامي & Ciparay & Kab. Bandung \\
\hline 27 & معهد الإحسان للتربية الإسلامية & Baleendah & Kab. Bandung \\
\hline 28 & & Cileunyi & Kab. Bandung \\
\hline
\end{tabular}

Daftar Nama-Nama Pesantren Berdasarkan Letak Geografis

Dari data nama-nama pesantren yang ada, dapat dikalisifikasikan lagi berdasarkan struktur Bahasa Arab menjadi: 1) sturktur badal sebanyak 7 data; 2) struktur idhofat sebanyak 17 data; 3 ) struktur shifat sebanyak 1 data; dan 4) tidak berterima sebanyak 3 data.

2. Variasi Bahasa dalam Penulisan Nama-Nama Pesantren di Wilayah Bandung Raya

Hasil pengamatan penulis dan kalsifikasi di atas, maka dalam uraian ini akan dijelaskan variasi bahasa dalam penulisan nama-nama peseantren sebagai berikut:

a. Struktur Badal

8 | Kalamuna: P-ISSN: 2655-4267, E-ISSN: 2745-6943 
Variasi penulisan nama pesantren dengan menggunakan struktur badal dapat dilihat pada table di bawah ini:

\begin{tabular}{|c|c|}
\hline$\overline{\text { No }}$ & Nama \\
\hline 1 & مؤسسة التربية الإسلامية مفتاح الفلاح \\
\hline 2 & المعهد الإسلامي بس \\
\hline 3 & معهد ال \\
\hline 4 & المعهد دار ال \\
\hline 5 & المعهد الإسد \\
\hline 6 & معهد التربية الإسلامية \\
\hline 7 & المعهد الم \\
\hline
\end{tabular}

Tabel 4.2

Nama-Nama Pesantren dengan Struktur Badal

Dalam Bahasa Arab, badal merupakan struktur yang terdapat pada isim tawabi'artinya isim yang suka mengikuti kata atau struktur sebelumnya dari segi kedudukan dalam I'rab. Ar-ra'ini mendefinisikan badal sebagai berikut :

$$
\text { فعل تبعه في جميع إعر ابهابع المقصود بالحكم بلا و اسطة و إذا أبدل اسم من اسم أو فعل من }
$$

Artinya:

"Badal ialah tabi' yang dimaksudkan hanya hukumnya saja, tanpa memakai perantara. Apabila isim dijadikan badal dari isim yang lain, atau fi'il dijadikan badal dari fi'il yang lain, maka badal harus mengikuti mubdal minhu-nya dalam semua i'rabnya". 
Kalamuna, Vol. 2. No. 1, Januari 2021. $01-23$

Badal yang dipakai dalam penulisan nama-nama pesantren-pesantren dalam penelitian ini tergolong ke dalam badal kul min kul. As-Samira'i mendefinisikan badal kul min kul sebagai berikut:

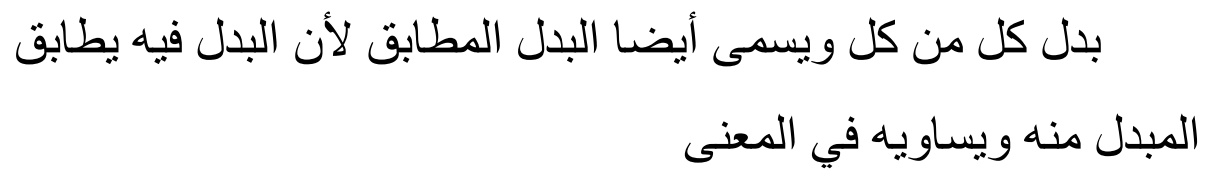

Artinya:

"Badal kul min kul dinamai juga badal muthabiq karena badal yang cocok dan sesuai dengan mubdal minhu-nya dalam hal makna”.

Strukur Bahasa Arab dengan menggunakan badal mengandung makna الإيضاح بعد الإبهامyaitu memperjelas sesuatu yang belum jelas. ${ }^{16}$

Berikut adalah nama-nama pesantren yang menggunakan struktur badal :

\section{1) مؤسسة التربية الإسلامية مفتاح الفلاح}

Pesantren ini berada di daerah cileunyi, penamaan pesantren ini menggunakan kata مؤسسةlang diidhafatkan kepada التربية الإسلامية مفتاح الفلاح kul (badal asy-syai min asy-syai) dari مؤسسة التربية الإسلامية. Berikut i'rab dari nama pesantren ini :

$$
\text { مؤسسة : مضاف الإسلامية : نعت أو صفة من التربية : مضاف إليه الفلاح : بدل من مؤسسة التربية الإسلامية }
$$

2) المعهد الإسلامي بستان الولدان

${ }^{16}$ As-Samira'i, Ma'ani an-Nahwi (Jordan : Dar al-Fikr li Ath-Thiba'ah wa An-Nasyr wa AtTauzi'. 2000), 209.

10 | Kalamuna: P-ISSN: 2655-4267, E-ISSN: 2745-6943 
Pesantren ini terletak di daerah cileunyi, penamaan pesantren ini menggunakan kata المعردyang dishifati oleh kata بستان الإسلامي dan selanjutnya nama pesantren ini yaitu berkedudukan menjadi badal kul minal kul. Berikut i'rab dari nama pesantren ini :

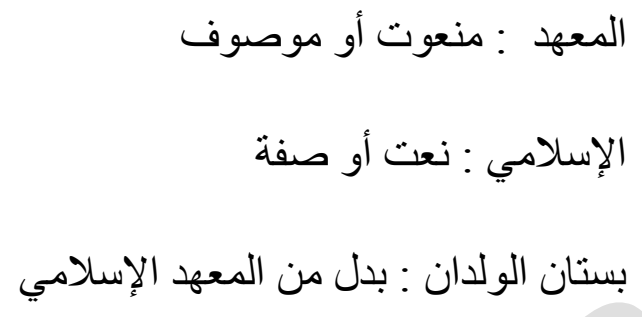

3) معهد القرآن الفلاح

Pesantren ini terletak di Cicalengka. Penamaan pesantren ini menggunakan kata seyang diidhafatkan kepada kata setelahnya yaitu القرآن. Adapun nama pesantren ini yaitu الفلاح|berkedudukan sebagai badal kul minal kul. Berikut i'rab dari nama pesantren ini :

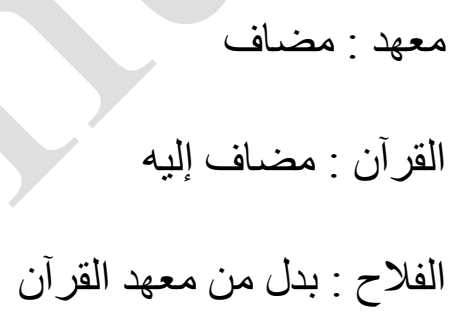

4) المعهد دار الفطرة لتحفيظ القرآن

Pesantren ini terletak di daerah Ciparay. Penamaan pesantren ini menggunakan

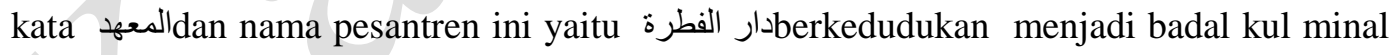
kul. Berikut i'rab dari nama pesantren ini :

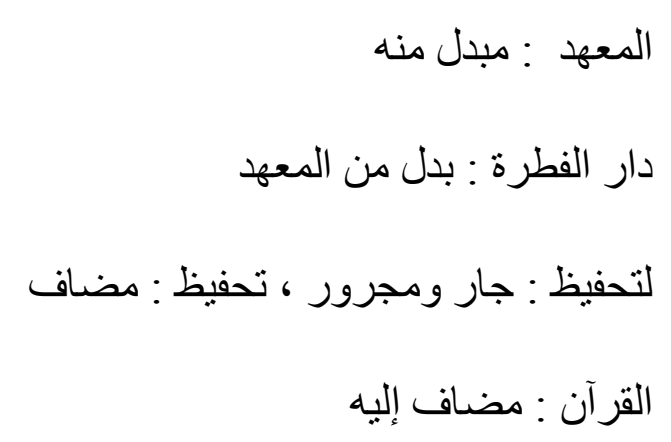

5)

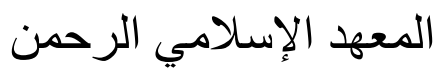


Kalamuna, Vol. 2. No. 1, Januari 2021. $01-23$

Pesantren ini terletak di daerah Cikancung. Penamaan pesantren ini menggunakan

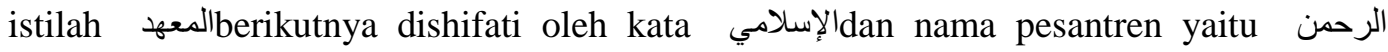
berkedudukan sebagai badal kul minal kul. Berikut i'rab dari nama pesantren ini :

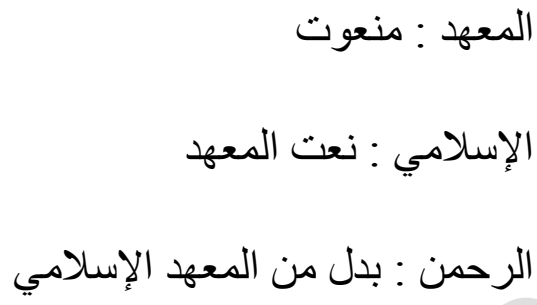

6) معهد التربية الإسلامية فتح المعين

Pesantren ini terletak di daerah Cileunyi. Penamaan pesantren ini menggunakan istilah معردyang diidafatkan kepada التربية الإسلامية. Dan nama dari pesantren ini yaitu فتح المعينberkedudukan sebagai badal kul minal kul. I'rab daru nama pesantren ini adalah sebagai berikut :

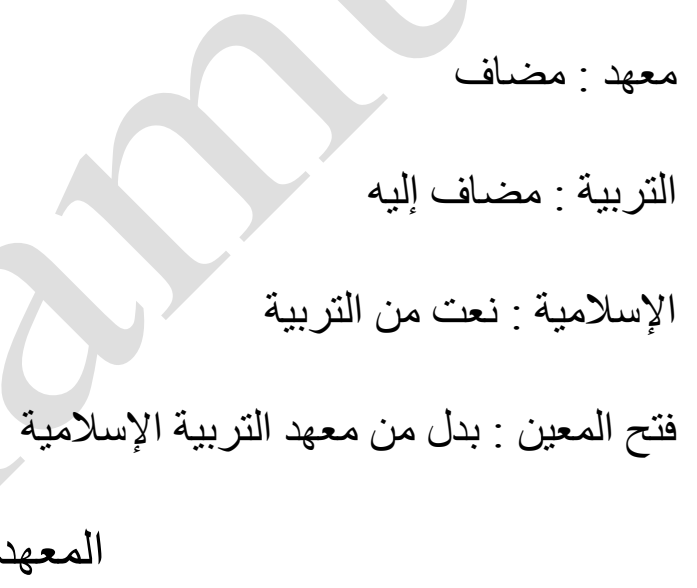

Pesantren ini terletak di daerah Mande. Penamaan pesantren ini menggunakan istilah المعراalu nama pesantren ini yaitu المختارية الإسلاميةberkedudukan sebagai badal kul minal kul. Berikut i'rab dari nama pesantren ini

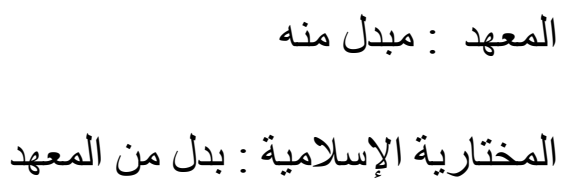

b. Struktur Idhafat

Variasi penulisan nama-nama pesantren dengan struktur idhofat merupakan struktur paling banyak yang dipilih oleh para pimpinan pesantren dalam memberikan nama untuk lembaganya. Daftar namanya bisa dilihat pada tabel berikut ini: 
Nama-Nama Pesantren... (Abdul Kosim)

\begin{tabular}{|c|c|}
\hline No & Nama \\
\hline 1 & معهد اللغة العربية \\
\hline 2 & معهد الر ائد الإسلامي \\
\hline 3 & معهد المرضبة الإسلامبة \\
\hline 4 & مؤسسة دار النشاء التربوية الإسلامية \\
\hline 5 & معهد رج \\
\hline 6 & معهد شمد \\
\hline 7 & معهد مفتاح \\
\hline 8 & 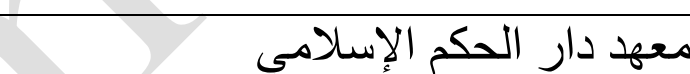 \\
\hline 9 & معهد الاتح \\
\hline 10 & الفلاح الإسلامي \\
\hline 11 & رحن السلفي \\
\hline 12 & مهعد المشاهدة الإسلامي \\
\hline 13 & معهد سومور باندونج الإسلامي \\
\hline 14 & معهد البشرية للتربية الإسلامية \\
\hline 15 & معهد بيت الأرقم الإسلامي \\
\hline 16 & معهد الإحسان للتربية الإسلامبة الحديثة \\
\hline
\end{tabular}


Kalamuna, Vol. 2. No. 1, Januari 2021. $01-23$

\begin{tabular}{|l|l|}
\hline 17 & معهد الإحسان الإسلامي \\
\hline
\end{tabular}

Tabel 4.3

Nama-Nama Pesantren dengan Struktur Idhofat

Idhofat dalam Bahasa Arab merupakan fenomena penggaabungan dua kata benda yang memiliki satu makna khusus. Ar-Raa'ini mendefinisikan idhafat dengan :

$$
\text { نسبة تقييدية بين الثبئين توجب لثانيهما جر ا أبدا }
$$

Artinya:

"Idhafat adalah menghubungkan dua kata benda (mudhaf dan mudhaf ilaih) yang menyebabkan kata benda yang keduanya beri'rab jar selamanya".

Struktur idhofat dalam perspektif makna ilmu nahwu mengandung makna yang sangat banyak, diantaranya ada yang bermakna takhsis dan menaqdirkan makna harafharaf jar seperti من، فى dan sebagainya. ${ }^{17}$

Berikut nama-nama pesantren yang menggunakan struktur idhafat:

1) معهد اللغة العربية

Pesantren ini terletak di daerah Cileunyi. Penamaan pesantren ini menggunakan kata tzedan diidhafatkan kepada kata setelahnya yang menjadi nama pesantren ini yaitu . اللغة العربية. Berikut i’rab dari nama pesantren ini :

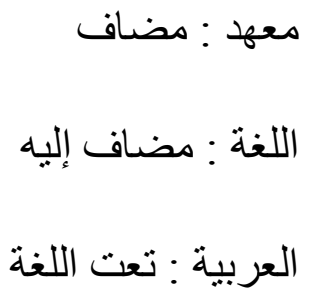

2) معهد الر ائد الإسلامي

${ }^{17}$ Ibid., 132.

14 | Kalamuna: P-ISSN: 2655-4267, E-ISSN: 2745-6943 
Pesantren ini terletak di daerah Cibiru. Penamaan pesantren inii menggunakan kata الإسلامي الرائد Dan diidhafatkan kepada nama pesantrennya yaitu. Dan kata berkedudukan menjadi shifat/na'at. Berikut i'rab dari nama pesantren ini :

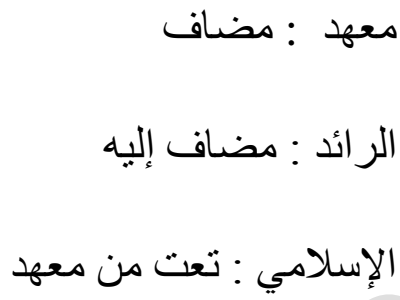

\section{3ع معد المرضية الإسلامية}

Pesantren ini terletak di daerah Cileunyi. Penamaan pesantren ini menggunakan kata المرضية Untuk lafadz الإسلامية Untang diidhafatkan kepada nama pesantrennya yaitu karena mu'annats maka ia menjadi na'at bagi lafadz المرضية. Berikut i'rab dari nama pesantren ini :

$$
\text { المعرد : مضاف الإسلامية : نعت من المرضية }
$$

4ؤسسة دار النشاء التربوية الإسلامية

Penamaan pesantren ini menggunakan istilah مؤسسةyang diidhafatkan kepada nama pesantren yaitu دار النشاء. Adapun التريسة الإسلاميةberkedudukan sebagai na'at. Berikut i'rab dari nama pesantren ini :

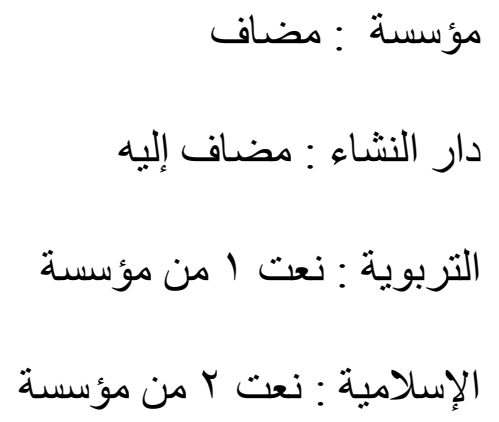

5عهد رجاء الهدى الإسلامي معي 
Kalamuna, Vol. 2. No. 1, Januari 2021. $01-23$

Pesantren ini terletak di daerah Cibiru. Penamaan pesantren ini menggunakan istilah zroyang diidhafatkan kepada nama pesantrennya yaitu رجاء الهُى. Adapun kata الإسلامي الإمي

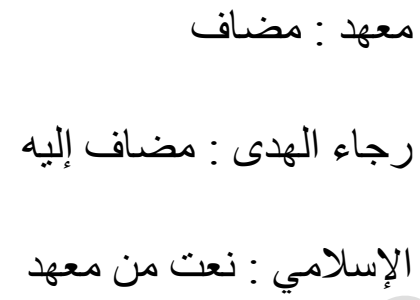

6) معهد شمس العلوم محمدية

Pesantren ini terletak di daerah Ujung Berung.

$$
\text { معهد شمس العلوم محمدية }
$$

\section{7) معهد مفتاح السعادة الإسلامي}

Pesantren ini terletak di daerah Banjaran. Penanamaan pesantren ini menggunakan istilah _aroyang diidhafatkan langsung kepada nama pesantren ini yaitu مفتاح السعادة. Adapun kata الإسلاميberkedudukan sebagai na'at/shifat. Berikut i'rab dari nama pesantren ini :

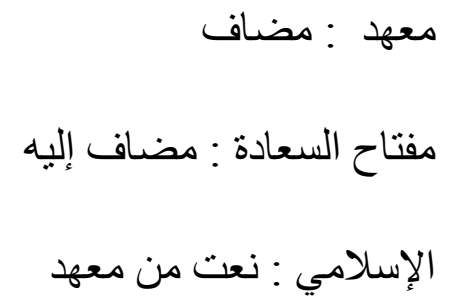

8) معهد دار الحكم الإسلامي

Pesantren ini terletak di daerah Pangalengan. Penamaan pesantren ini menggunakan istilah sosyang diidhafatkan langsung kepada nama pesantren ini yaitu دار الحكم ban kata الإسلامي berkedudukan sebagai na'at/shifat. Berikut i'rab dari nama pesantren ini :

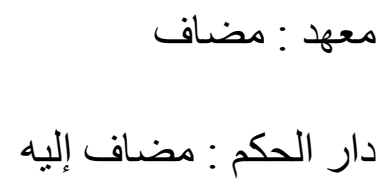




\section{9) معهد الاتحاد الإسلامي الفطرى}

Pesantren ini terletak di daerah Pangalengan. Penamaan pesantren ini menggunakan istilah sesyang diidhafatkan kepada kata selanjutnya yaitu الاتحاد. Sedangkan kata الإسلاميberkedudukan sebagai na'at. Berikut i'rab dari nama pesantren ini :

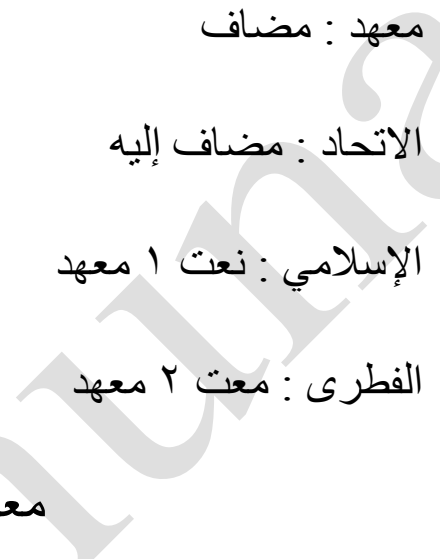

Pesantren ini terletak di daerah Pacet. Penamaan pesantren ini menggunakan istilah sesyang diidhafatkan kepada nama pesantren ini yaitu مصباح الفلاح berkedudukan sebagai na'at. Berikut i'rab dari nama pesantren ini :

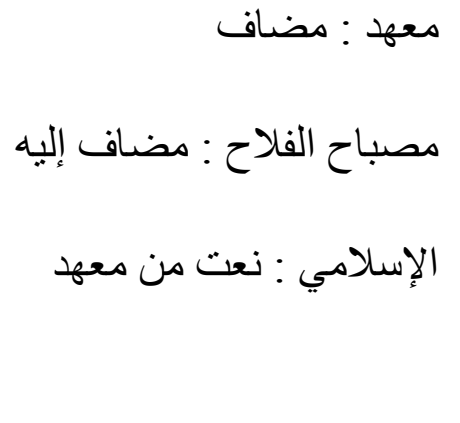

Pesantren ini terletak di daerah Pacet. Penamaan pesantren ini menggunakan istilah

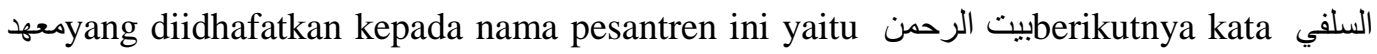
berkekdudukan sebagai na'at. Berikut i’rab dari nama pesantren ini :

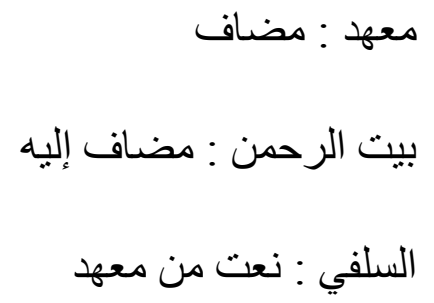


Kalamuna, Vol. 2. No. 1, Januari 2021. $01-23$

12)

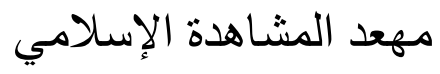

Pesantren ini terletak di daerah Cimahi. Penamaan pesantren ini menggunakan istilah sعyang diidhafatkan kepada nama pesantren ini yaitu المشاهدة:sedangkan kata الإسلامي الإمي

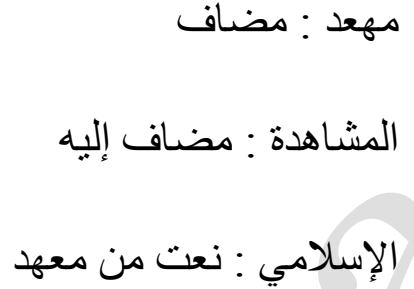

13)

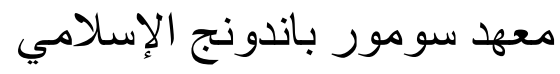

Pesantren ini terletak di daerah Cililin. Penamaan pesantren ini menggunakan istilah sعyang diidhafatkan kepada nama pesantren ini yaitu سومور باندونجsedangkan kata الإسلامي berkedudukan sebagai na'at. Berikut i'rab dari nama pesantren ini :

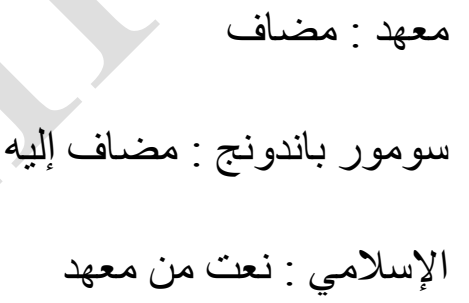

14)

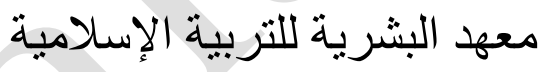

Pesantren ini terletak di daerah Cigondewah. Penamaan pesantren ini menggunakan istilah seyang diidhafatkan kepada nama pesantren ini yaitu البشرية adapun للتربية الإسلاميةmerupakan jar+majrur+sifat. Berikut i'rab dari nama pesantren ini :

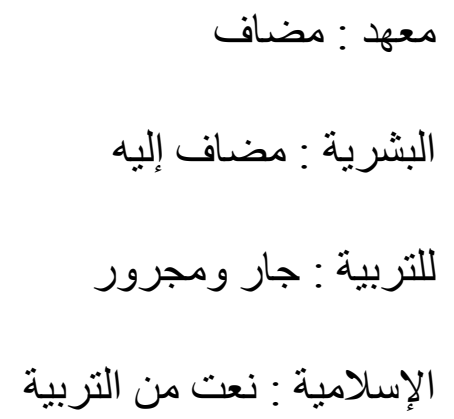

15)

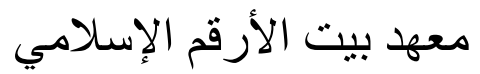


Pesantren ini terletak di daerah Ciparay. Penamaan pesantren ini menggunakan istilah معردdang diidhafatkan kepada nama pesantren ini yaitu بيت الأرقم kata berkedudukan sebagai na'at. Berikut i'rab dari nama pesantren ini :

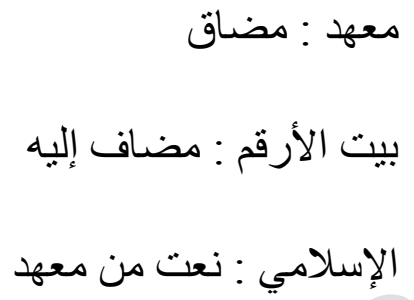

16)

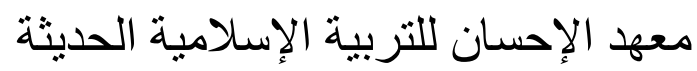

Pesantren ini terletak di daerah Baleendah. Penamaan pesantren ini menggunakan istilah اللتربية الإحسان sesusunang diidhafatkan kepada nama pesantren ini yaitu merupakan jar+majrur dan الإسلامية الحديثةberkedudukan sebagai na'at. Berikut i'rab dari nama pesantren ini :

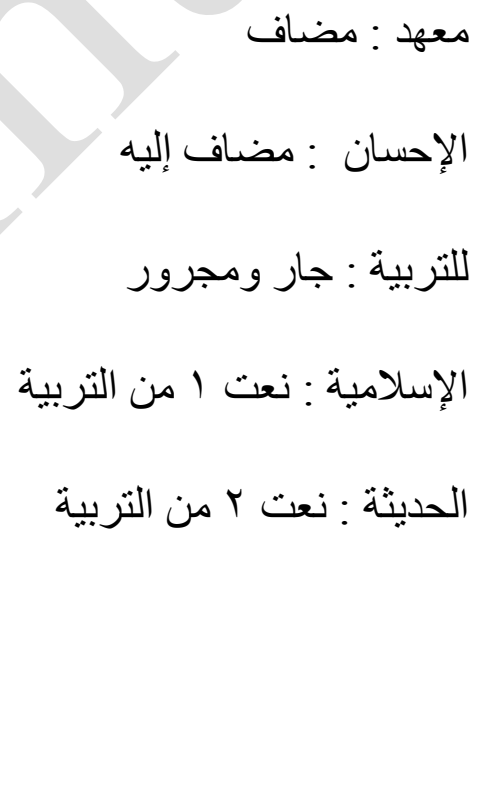

17)

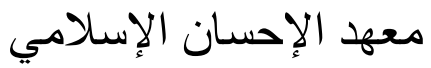

Pesantren ini terletak di daerah Cileunyi. Penamaan pesantren ini menggunakan istilah معردadang diidhafatkan kepada nama pesantren ini yaitu الإسلامي adata berkedudukan sebagai na'at. Berikut i'rab dari nama pesantren ini :

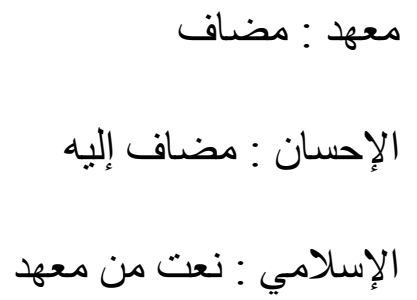


Kalamuna, Vol. 2. No. 1, Januari 2021. $01-23$

c. Struktur Shifat

Penulisan nama pesantren dengan struktur sifat dalam penelitian ini hanya ditemukan satu data, yaitu:

\begin{tabular}{|c|c|}
\hline No & Nama \\
\hline 1 & \\
& \\
\hline
\end{tabular}

Tabel 4.4

Nama Pesantren dengan Struktur Shifat

Struktur shifat dalam kaidah Bahasa Arab merupakan termasuk isim tawabi, yaitu isim yang suka mengikuti kata atau struktur sebelumnya, dalam hal ini adalah maushuf atau yang dishifatinya. Ar-raa'ini mendefinisikan naat/shifat sebagai berikut :

$$
\text { النعت هو التابع المشتق أو المؤول به المباين للفظ متبو عه }
$$

Artinya:

"Shifat adalah tabi' (lafadz yang mengikuti) yang musytaq atau muawwal bih yang menjelaskan lafadz yang diikutinya”.

Secara makna dalam perspektif ilmu nahwu, struktur sifat memiliki makna takhshis atau mengkhususkan sesuatu dibandingkan dengan yang lainnya. ${ }^{18}$

Adapun nama pesantren yang menggunakan nama pesantren yang menggunakan struktur shifat adalah :

\section{1) المعهد اللغوي}

Pesantren ini terletak di daerah Cibiru. Penamaan pesantren ini menggunakan kata المعهدkata ini menjadi man'ut bagi na'at/shifat setelahnya yaitu اللغوي. Berikut i'rab dari nama pesantren ini :

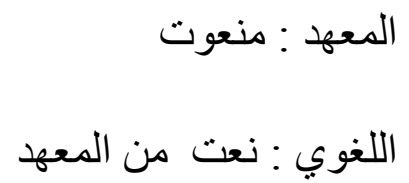

d. Struktur yang Tidak Berterima

${ }^{18}$ Ibid., 182.

20 | Kalamuna: P-ISSN: 2655-4267, E-ISSN: 2745-6943 
Hasil pengamatan penulis dalam penelitian ini, dari data yang berjumlah 28 ada 3 data yang secara kaidah Bahasa Arab tidak berterima atau dengan ilmu yang dimiliki penulis, struktur tersebut tidak sesuai dengan kaidah yang berlaku. Data-data yang dimaksud adalah sebagai berikut:

\begin{tabular}{|c|c|}
\hline No & Nama \\
\hline 1 & المعهد الإسلامية السلفية نهج السلام \\
\hline 2 & المعهد الإسلامبة الحديثة خير أمة التسليم الثانية \\
\hline 3 & \\
\hline
\end{tabular}

Tabel 4.5

Nama-Nama Pesantren dengan Struktur yang Tidak Berterima

1) المعهد الإسالامبة السلفية نهج السالام

Pesantren ini terletak di daerah Cileunyi. Penamaan pesantren ini menggunakan

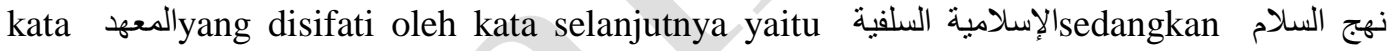
menjadi badal kul minal kul.

Secara kaidah bahasa Arab, terdapat kekeliruan dalam penamaan ini, yaitu pada

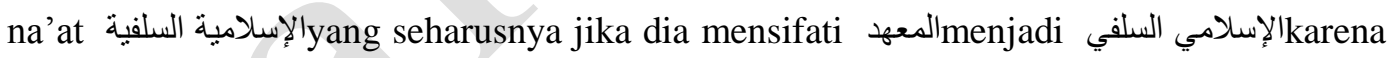
na'at dan man'ut harus muthabaqah (selaras) diantaranya pada jenis (mudzakkar/muannats). Ar-Raa'ini menjelaskan :

$$
\begin{aligned}
& \text { و النعت يتبع المنعوت في رفعه ونصبه وخفضه وتعريفه وتنكيره ثم إن رفع } \\
& \text { ضمير المنعوت المسنتر فيه تبعه أيضا في تذكيره وتأنيثه وفي إفر اده وتثنيته وجمعه. }
\end{aligned}
$$

Artinya:

"Na'at itu mengikuti man'ut dalam hal rafa', nashab, khafadh, ta'rif dan tankir. Kemudian jika dhamir man'ut yang dikandungnya dirafa 'kan, maka na'at mengikutinya pula dalam hal tadzkir dan ta 'nits, begitu pula dalam hal ifrad, tatsniyah, dan jamak".

Sebagai opsi, penulis mengusulkan nama yang dianggap lebih tepat yaitu

$$
\text { ا ـ المعهد الإسلامي السلفي نهج السلام }
$$


Kalamuna, Vol. 2. No. 1, Januari 2021. $01-23$

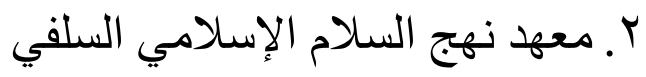

2) المعهد الإسلامية الحديثة خير أمة

Pesantren ini terletak di daerah Cileunyi. Penamaan pesantren ini menggunakan kata الإسلامية الحديثة Sedangkan nama pesantren ini yaitu خير أمةberkedudukan menjadi badal kul minal kul. Terdapat kekeliruan secara kaidah bahasa الإسلامي الإسلامية الحديثة dalam seharusnya sunan kata nama pesantren ini, yaitu pada الحديثkarena ia menshifati kata yang sebelumnya yang mudzakkar (المعهد). Sebagai mana telah dijelaskan sebelumnya.

Sebagai opsi, penulis mengusulkan nama yang dianggap lebih tepat yaitu

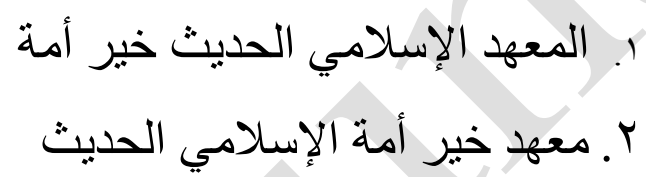

3) معهد التسليم الثانية

Pesantren ini terletak di daerah Pangalengan. Penamaan pesantren ini menggunakan istilah ł sesyang diidhafatkan langsung kepada nama pesantren ini yaitu . Terdapat kekeliruan secara kaidah bahasa dalam struktur nama pesantren ini, yaitu pada kata الثانيةyang seharusnya الثانيkenarena menjadi shifat/na'at dari kata sebelumnya yang mudzakkar.

Sebagai opsi, penulis mengusulkan nama yang dianggap lebih tepat yaitu

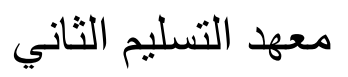

\section{E. Penutup}

Berdasarkan pengamatan dan hasil analisis data, ditemukan bahwasannya 7 data (25\%) menggunakan struktur badal, 17 data (61\%) menggunakan struktur idhofat, 1 data (3\%) menggunakan struktur sifat, dan 3 data (11\%) strukturnya tidak berterima secara kaidah Bahasa Arab. Perbedaan struktur ini tentunya berdampak terhadap karakteristik makna yang terkandung di dalammnya. Dalam penelitian ini struktur badal mengandung makna Al-Idhahu Ba'da AlIbham yang artinya memperjelas sesuatu yang belum jelas, kemudian struktur idhofat mengandung makna haraf jar yang berarti kepemilikan, tempat, dan lokasi. Struktur shifat mengandung makna takhshis atau mengkhususkan sesuatu dari yang masih umum. 
Ade Nandang dkk. 2018. Pengantar Linguistik Arab. Bandung: PT Remaja Rosdakarya

Amrulloh, Muhammad Afif, and Ro'fat Hizmatul Himmah. 2017. “Analisis Perubahan Morfologis Pembentukan Ta'rib Dan Pembelajaran.” Tadris: Jurnal Keguruan dan Ilmu Tarbiyah 2(2): 87.

Ar-Raa'ini, 2019. Mutammimh Ajurumiyah. Bandung: Sinar Baru Algesindo

As-Samira'i. 2014. An-Nahwu al-Arabi : ahkamun wa ma'anin. Dimaskus : Dar ibn Katsir

As-Samira'i. 2000. Ma'ani an-Nahwi. Jordan : Dar al-Fikr li Ath-Thiba'ah wa An-Nasyr wa AtTauzi'

Fatimah Djadjasudarma. 2010. Metode Linguistik. Bandung: Refika Aditama

Lailatul Zuhriyah dkk. 2018. Proses Afiksasi Morfologi Isim (Nomina) dalam Bahasa Arab. Malang: Adabiyat

Mahsun. 2014. Metode Penelitian Bahasa. Jakarta: Rajawali Pers

Muhammad Afifudin Dimyati. 2016. Madkhal Ila Ilmi Al-Lughah Al-Ijtima’i. Surabaya: Lisan Arabi

Muhammad Ali Al-Khuli.1982. Asalibu Tadris Al-Lughah Al-Arabiyah. Riyadh

Muhammad Ali Al-Khuli. 1991. A Dictionary of Throretical Linguistics. Beirut: Librarie Du Liban

Pateda, Mansoer. 1991. Linguistik Terapan. Yogyakara : Nusa Indah

Ramdiani, Yeni et al. "Sintaksis Bahasa Arab (Sebuah Kajian Deskriptif)."

Rahmawati, Ana. 2018. "Bentuk Interferensi Sintaksis Bahasa Indonesia Dalam Berbahasa Arab." Ijaz Arabi Journal of Arabic Learning 1(2): 122-29.

Sudaryanto. 2015. Metode dan Aneka Teknik Analisis Bahasa.Yogyakarta: USD Press

Tajudin Nur. 2018. Morfologi Bahasa Arab. Sumedang: Unpad Press

Tajudin Nur. 2018. Sintaksis Bahasa Arab. Sumedang: Unpad Press

Ubaidillah. 2012. "Interferensi Penggunaan Nama Diri Berbahasa Arab Di Indonesia (Sebuah Kajian Sosiolinguistik)." Adabiyyāt: Jurnal Bahasa dan Sastra 10(1): 1. 
Kalamuna, Vol. 2. No. 1, Januari 2021. 01 - 23

24 | Kalamuna: P-ISSN: 2655-4267, E-ISSN: 2745-6943 